\title{
Achieving Sustainable Development Goals by Adopting the Blue-Green Economic Provisions: An Analysis of Opportunities and Challenges of Sri Lanka
}

\author{
Nipuni Dissanayake 1 (D) , Athula Withanawasam ${ }^{2}$ (D) and Athambawa Sarjoon ${ }^{3}$ (D) $\triangle$ \\ ${ }^{123}$ Department of Political Science, Faculty of Arts, University of Peradeniya, Peradeniya 20400, Sri Lanka \\ $\triangle$ Corresponding Author: Athambawa Sarjoon, E-mail: sarjoona@gmail.com
}

\author{
ARTICLE INFORMATION \\ Received: May 11, 2021 \\ Accepted: June 17, 2021 \\ Volume: 3 \\ Issue: 6 \\ DOI: 10.32996/jhsss.2021.3.6.3
}

\section{KEYWORDS}

Sustainable Development, BlueGreen Economy, Sustainable Development Goals (SDGs), Sri Lanka.

\section{ABSTRACT}

With the introduction of the Sustainable Development Goals (SDGs) in 2015 by the United Nations Development Programme (UNDP), Sri Lanka has given priority to the SDGs in its main development agenda and attempting to achieve them by working towards the fulfilment of the basic needs and improving the living standards of the people, progressively alleviating poverty, eliminating all forms of discrimination and inequalities and establishing a society based on social justice and human security. In this regard, Sri Lanka has both prospects and obstacles in the achievement of SDGs. This paper has paid attention to explore the available opportunities and challenges in the journey of achieving SDGs by adopting the Blue-Green economic provisions in Sri Lanka. Additionally, it has also been attempted to present some effective recommendations to overcome those impediments since identifying effective solutions is equally important in finding ways to overcome those impediments. Using the existing secondary literature available in the forms of literary books, journal articles and reports, this study has found that it is a timely requirement of the Government of Sri Lanka (GoSL) to adopt the Blue-Green economic provisions to get back the current unsustainable development of Sri Lanka on the right track and achieve the SDGs by 2030.

\section{Introduction}

Nation-building and achieving the desired economic growth have become two major issues that Sri Lanka has been striving to accomplish for several decades. The core of sustainable development is that it is a modern development strategy that aims to balance the different and competing needs of the environment, society and economy of the current world. The main deliberative outcomes of sustainable development are combating climate change, reducing economic inequality and poverty, innovation and achieving sustainable consumption practices. Enhancing social justice and creating a free and fair society are also among other priorities of sustainable development. Accordingly, the measures that come under sustainable development include uplifting the well-being of every person, expanding social inclusion and creating an equal and equitable society based on a fair chance for all irrespective of all forms of discriminations based on gender, ethnicity, religion, race, political alignment etc. Blue-Green economic strategy is known as one of the important parameters to achieve sustainable development. The SDGs also emphasize the importance of adopting Blue-Green economic principles in national development policies to ensure the sustainability of sociopolitical and economic development. This paper has attempted to identify the available opportunities, challenges and alternatives of the task of meeting the SDGs while giving priority to the Blue-Green economic provisions in the Sri Lankan context. The SDGs and the vision of government towards the Blue-Green economy matter to all of us because everyone has a shared responsibility for our future and that of our planet.

\section{Methodology}

This study is descriptive, interpretive and qualitative in nature. The secondary data, which were accessed from different sources such as books, academic journal articles, newspapers, reports of the UN agencies and other institutions, and the internet, has

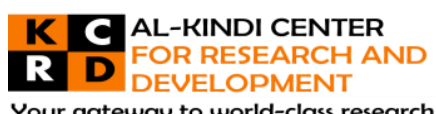

Your gateway to world-class research

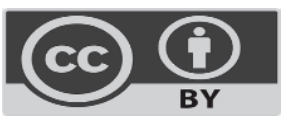

Published by Al-Kindi Center for Research and Development. Copyright (c) the author(s). This open access article is distributed under a Creative Commons Attribution (CC-BY) 4.0 license 
been mainly used in this study. These sources include the present status of achieving SDGs in the Sri Lankan context from different perspectives. Besides, they have also analyzed the conceptual nexuses between the SDGs and the Blue-Green economy. The available opportunities and challenges encountered by Sri Lanka when achieving the SDGs by adopting the Blue-Green economic strategies have been assessed and reported in this paper in the form of direct quotations, quotations of others, summaries, and the authors' interpretation, all of which contribute to the findings of this study.

An interpretive survey helps to build an understanding of certain processes and circumstances. Hence, interpretive studies need the researchers to go beyond presenting ordinary explanations of the situation. They require researchers to 'analyze and interpret' the circumstance for the reader based on empirical data. In development and policy studies, the interpretive approach aims to develop methods for expanding the understanding of different development strategies that can be used by various scholars of different disciplines to enhance their knowledge. This approach does not intend to promote or underestimate any available opportunity or challenge.

This article is divided into six major parts, with concluding remarks at the end. The first part presents a brief description of the theoretical basis of the SDGs. The second section provides a brief introduction to the Blue-Green economic approaches. In the third part, it has been examined the available opportunities in Sri Lanka when achieving the SDGs by following the Blue-Green economic provisions. In the fourth section, it has been investigated the impediments encountered by Sri Lanka when achieving the SDGs through the Blue-Green economic approach. The fifth section provides an analysis of the possible solutions that can be incorporated by Sri Lanka to overcome those barriers. In conclusion, this study has attempted to identify the aptitudes, obstacles and alternatives of Sri Lanka when making success the task of achieving SDGs by adopting Blue-Green economic strategies.

\section{Sustainable Development Goals: A Brief Introduction}

The concept of sustainability has a long history that dates back to the 1970 s and gradual development in its theoretical foundation throughout that history (See Straaten \& Tylecote, 1997; Schrijver, 2010). Accordingly, the academic discourse of sustainability has various spectrums and many scholars have identified different dimensions of sustainability. Thomas (2015), sees sustainability as a process that concentrates prevention of exploitation of resources by human activities and their necessity of satisfying needs. Ben-Eli (2015) defines the concept of sustainability as a vigorous equilibrium in the activities between the population and the carrying capacity of the environment such that the people attempt to benefit from its full capacity without causing adverse effects to the environment. Stoddart et al. (2011) have identified sustainability as the fair distribution of natural resources intra-generationally and inter-generationally through the socio-economic activities within the limited ecosystem.

Development as a broad theory and practice has a plethora of meanings. Development is a multidimensional process that reduces inequality and eradicates extreme poverty through adjusting in social structures and institutions, economic directions and attitudes of the society (Todaro \& Smith, 2006). Reyes (2001) has perceived development as a social condition that addresses the needs of the population more prudently and sustainably by utilizing natural resources and systems in the same manner.

According to Mensah (2019), sustainable development is a multi-facet concept with many different definitions, meanings and interpretations. Comporek et al. (2021) have identified three elements of sustainable development as economic growth, social equity for fulfilling the requirements of the present generation, and environmental protection to ensure the potential of meeting the needs of present and future generations. United Nations Development Program (UNDP) presents a comprehensive definition of sustainable development in 2015 parallel to the introduction of SDGs. According to the UNDP, "Sustainable development is the development that meets the needs of the present, without compromising the ability of future generations to meet their own needs" (United Nations, 2015:16). In other words, it reminds the present generation about their responsibility in consuming the resources of the Earth. It must be saved the natural resources for the next generations while preserving the environment. Klarin (2018), mentions that the theoretical basis of sustainable development is the assurance of human needs while respecting certain restrictions in the environment. Sustainable development is about employing more environmentally friendly strategies in getting things done. More viable approaches present under sustainable development support not only for the betterment of the future but also for the present. The principles of sustainable development insist that we need to change our lifestyles with a long-term view of the conservation of the environment.

In 2015, the UNDP introduced the agenda of SDGs with a set of 17 aspirational 'Global Goals' with 169 targets and 244 indicators between them to be achieved by 2030 (United Nations, 2015). The SDGs succeeded the previous United Nations Agenda of Millennium Development Goals (MDGs) (United Nations, 2016). The set of SDGs is listed below. 


\section{The List of the Sustainable Development Goals}

Goal 1: End poverty in all its forms everywhere.

Goal 2: End hunger, achieve food security and improved nutrition and promote sustainable agriculture.

Goal 3: Ensure healthy lives and promote well-being for all at all ages.

Goal 4: Ensure inclusive and equitable quality education and promote lifelong learning opportunities for all.

Goal 5: Achieve gender equality and empower all women and girls.

Goal 6: Ensure availability and sustainable management of water and sanitation for all.

Goal 7: Ensure access to affordable, reliable, sustainable and modern energy for all.

Goal 8: Promote sustained, inclusive and sustainable economic growth, full and productive employment and decent work for all.

Goal 9: Build resilient infrastructure, promote inclusive and sustainable industrialization and foster innovation.

Goal 10: Reduce inequality within and among countries.

Goal 11: Make cities and human settlements inclusive, safe, resilient and sustainable.

Goal 12: Ensure sustainable consumption and production patterns.

Goal 13: Take urgent action to combat climate change and its impacts.

Goal 14: Conserve and sustainably use the oceans, seas and marine resources for sustainable development.

Goal 15: Protect, restore and promote sustainable use of terrestrial ecosystems, sustainably manage forests, combat desertification, and halt and reverse land degradation and halt biodiversity loss.

Goal 16: Promote peaceful and inclusive societies for sustainable development, provide access to justice for all and build effective, accountable and inclusive institutions at all levels.

Goal 17: Strengthen the means of implementation and revitalize the global partnership for sustainable development (United Nations, 2015).

The national governments, private sector, civil society organizations by themselves are striving today for the accomplishment of the agenda of SDGs. Today the Inter-Governmental Organizations (IGOs) and International Non-Governmental Organizations (INGOs) are implementing myriads of projects within the field of SDGs based on the International Cooperation principles in their partner states. The SDGs and the world's cooperation in the achievement of them can mobilize us in facing the current catastrophes, including the drastic climate changes and massive, unpredictable economic recessions.

\section{The Blue-Green Economic Policy: The Creator of New Prospects in the Economy}

The Blue-Green Economy is a modern development approach that has been formulated concerning ecological preservation and obtaining optimal benefits from the green environment and oceans without harming or exploiting them. Blue-Green Economy can be divided into two fields as the Blue Economy and the Green Economy.

United Nations Environment Program (UNEP) clarifies the concept of Green Economy as "it results in improved human wellbeing and social equity, while significantly reducing environmental risks and ecological scarcities" (Fedrigo-Fazio and Brink, 2012: 3). In the contemporary context, the Green Economy is known as an agenda of operational policy that aims to achieve measurable improvement in the environment. Moreover, it has been accepted that Green Economy links with sustainable development as one major 'pillar' of it (Georgeson et al., 2017). The classic notion of the Green Economy is that many of the prevailed development approaches have caused severe environmental degradations in a highly devastating manner and therefore, economic development should be considered as a component of the environment in which it resides (UNEP et al., 2012). By today, the principles of the Green Economy have developed and spread into many new areas. Now, it is considered that the Green Economy is driven equally by environmental sensitivity and creating new opportunities with the understanding that Green Economy can invent new economic development opportunities like opening up new career prospects. Hence, the United Nations Organization has once defined Green Economy as 'a new engine of growth' (United Nations, 2012).

There are several major concerns in the Green Economy. One of the major aspects is the given priority to energy efficiency practices. The Green Economic approach depends a lot on renewable energy sources like wind and solar, instead of nonrenewable petroleum-based resources. Introducing 'green construction methods' to massive city and urban development projects and also to small scale constructions is another aspect of the Green Economy. Clean transportation has an important place in Green Economy. In there, using more non-carbon and low-carbon emission methods of transportation, such as cycling and switching into public transportation, than using private motor vehicles are among suggestions of clean transportation. The Environmental Management aspect which plays a major role in Green Economy explains getting optimal benefits from the ecosystem without damaging it (See: Georgeson et al., 2017; Loiseau et al., 2016; Allen, 2012). One of the main characteristics of the Green Economy is the priority given to clean and safe agriculture, forestry and land management practices. Green Economy thoroughly advocates organic food production, fair trade, and reforestation. The strategies of Green Economy include the areas such as eco-friendly and cruelty-free food manufacturing industries. Green tourism which is also popular as eco-tourism around

Page | 20 
the world today, is also an important provision of the Green Economy. It is noteworthy of reminding that Green Economy needs the genuine cooperation of the government, including public services delivery mechanism and other public regulatory frameworks such as research, design and consultation. 'Green Technology' has gained rapid popularity within the major stream of the Green Economy (See: Guo et al., 2020). The practices of Green Technology have linked with eco-friendly (clean and safe) and new technical innovations that encourage sustainability. In this subfield, the production and transmission of energy from renewable sources, water purification practices, sewage treatment methods, solid waste management techniques, and air pollution reduction methods, etc. are some of the areas which have high global attention.

One of the most important recommendations of the Green Economy is assigning a certain, proper value (an economic value) to the services provided by the natural ecosystem. The high efficiency in resources and a great degree of social inclusiveness is very significant in the Green Economy. Green Economy often emphasizes generating quality, green jobs that have reasonable pay. High tax or fines on situations of exceeded carbon emission practices is also one recommendation of the Green economy. Furthermore, the Green Economy guides in establishing robust recycling, reusing and repairing strategies in every locality based on the principles of minimizing waste. Borel-Saladin and Turok (2013) have insisted that the Green Economy paves the way for transforming the current imbalanced economic activities into healthier and more inclusive economies by paying attention to the warning signs of the environment.

The Blue Economy (BE) has been defined in many ways by different scholars and institutions. Okafor-Yarwood et al. (2020) indicate that the concept of BE is increasingly being popularized by scholars and policymakers by applying it as a useful approach in conserving the oceans and their resources. The United Nations Conference on Trade and Development (UNCTAD) elaborated the $\mathrm{BE}$ as the economic and trade activities that concentrate on the ocean-based marine environment, associated biodiversity, ecosystems, species, and genetic resources whilst ensuring its conservation (UNCTAD, 2014). The World Bank has identified the Blue Economy as "comprising the range of economic sectors and related policies that together determine whether the use of oceanic resources is sustainable" (World Bank, 2017:vi). The theoretical foundation of the Blue Economy is the divergence of prevailed imbalanced socio-economic development from ocean-related activities and massive environmental deteriorations (The World Bank, 2017). Blue Economy also attempts at enhancing economic growth, social inclusion, and the preservation or improvement of traditional ocean-related livelihoods, simultaneously promoting sustainability of oceans and coastal regions. The main characteristics of the Blue Economy include cross-sectorial nature, social inclusiveness marked by all stakeholder participation, innovation, applying well-informed, precautionary and adaptive practices, ensuring transparency and accountability, formulate action plans based on a long-term view on environment and economy (See: Wenhai et al., 2019). Those characteristics show variations in different sociopolitical and economic contexts.

It is essential to participate in both the public and private sectors in establishing a Blue economy in a particular state. Promote entrepreneurship activities related to the Blue Economy is one of the outstanding provisions in the Blue Economy. Setting clear goals and assessing the performances regularly, facilitating proper information flow with sharing best practices and learned lessons should also be done systematically to develop the most applicable model of the Blue Economy for a certain geographical context. The ocean is considered the seventh-largest contributor to the world economy since its annual value of goods and services of US\$ 2.5 trillion (Global Environment Facility, 2018). Many small island nations depend on the income gain through marine-based economic activities. Billions of people depend on the sea for food and livelihoods. As a result, oceans are highly valuable in sustaining life on Earth. The United Nations Conference on Sustainable Development (UNCSD) known as the "Rio+20" Summit, brought out the important message of the danger of over-exploiting marine resources as a result of the bad consumption patterns (UNDP, 2012).

Some important subfields have been developed in the Blue Economy with its gradual expansion. Blue Energy is one of the significant areas in the Blue Economy. Blue Energy resources include offshore wind power, tidal and wave power, ocean thermal energy conversion, etc. Aquaculture, maritime, coastal and cruise tourism, deep-sea and short-sea fishing and shipping, seabed mining, activities related to marine biotechnology such as purifying resources for the pharmaceutical industries, desalination are also some main and widely-practiced activities in the Blue Economy. Modern career paths in coastal protection and maritime security and surveillance activities are also rapidly popularizing in the Blue Economic field today. In order to achieve the deliberated economic and social outcomes from the above-mentioned economic-related activities, proper formulation of strategies is highly essential. In this scenario, the relevant authorities such as the national governments, IGOs, INGOs and civil society organizations should be able to come into one line, identify their roles and share one goal to develop the most appropriate strategies in their unique geopolitical, socio-cultural and economic circumstances. 


\section{The Available Opportunities for Sri Lanka in Achieving the Sustainable Development Goals by Adopting the Blue- Green Economic Provisions}

Geographically, Sri Lanka is located in a vantage ground in the Northern Indian Ocean. It has strategically positioned itself as one of the neighbours to the fast-growing trading nation - India. Sri Lanka is a crucial hub of the 'One Belt One Road' (OBOR) initiative of China. ${ }^{2}$ It is one of the most vital East-West global shipping lane routes near Sri Lanka. Sri Lanka has valuable ocean resources, within its Exclusive Economic Zone (EEZ) and beyond the continental shelf of the Bay of Bengal. The coastal line of Sri Lanka is approximately $1600 \mathrm{~km}$ in length, enriches with many natural resources, natural harbours and huge biodiversity (Bio Energy Association of Sri Lanka. 2016).

Sri Lankan coasts comprise a huge stock of living and nonliving marine resources. Hence, it is essential to unlocking the value of the resources of the ocean sustainably. Fishery resources are abundant in both shallow and deep-sea of Sri Lanka and those have not tapped yet for getting the maximum benefits from them. Fisheries in the deep sea of Sri Lanka have the potential to access the international market. One of the most vital steps by which the government of Sri Lanka can take is to give global leadership in sustainable fisheries management practices empowered by sustainability and the modern Blue economic approach.

The marine zone of Sri Lanka consists of rich marine biological resources including corals and other medicinal herbs. In this regard, first, it is essential to carry out proper scientific-based researches to identify the value of those assets in various industries with the cooperation of government, private sector, INGOs and other international agencies. If Sri Lanka can develop this sector, it has great potential to introduce new resources for the pharmaceutical and other high-tech industries in the developed countries.

The coastal line and the shallow seabed of Sri Lanka contain a huge variety of mineral resources. Still, they are untouched and no proper attention is paid. The coastal sediments contain titanium and zirconium tin which have an excellent international market (Kuo, 2015). Developed countries use them as raw materials for different products starting from biomedical implants to aircraft applications. In there, Sri Lanka can refine them and use them for domestic industries or directly export them as raw materials. Nevertheless, Sri Lanka can gain more profit rather than merely exporting them as raw materials, if it has the technology to convert those mineral compounds into value-added products. Simultaneously, Sri Lanka can double the profit, if it follows the provisions that come under the Blue-Green economic provisions like, 'clean industries' which has a high demand in the global market. The active participation of the government and the national policymakers, research institutions and private sector are also essential in making this a reality.

Sri Lanka has great potential to establish port facilities with a low carbon footprint. ${ }^{3}$ Supplying oceanic navigation facilities and port facilities can attract huge foreign revenue to the country. Sustainable economic development could be achieved not only by making Sri Lanka a hub for container trans-shipment but also could be attracted more foreign investments by developing an oceanic navigation system with sea voyages and modern seaports in an eco-friendly structure. Sri Lanka can become a vital regional logistics management hub by using its most advantageous location in the Indian Ocean if it can attract investments to cover the initial cost.

There are many other prospects related to the marine economy, such as becoming a natural gas storage hub, oil and gas exploration rig building hub, etc. There are abundant gateways to establish a shipbuilding hub, regional seismic survey and ship deployment hub centred in the Sri Lankan coastal line. In this case, the Sri Lankan government needs the active participation of the private sector and foreign companies to implement those projects. It is noteworthy to mention again that all the above detailed modern ocean-related industries should utilize energy conservation strategies and pollution-free practices to be certified as industries of eco-friendly with zero environmental damage.

Additionally, Sri Lanka has an excellent opportunity to develop the tourism industry around the coastal regions - marine-based tourism. Today the 'Blue-Green tourism industry' is rapidly developing in many countries. Sri Lanka has a huge potential to introduce internationally popular oceanic and beach sports like yachting, sailing, swimming, diving, surfing, water skiing, beach volleyball, and other recreational water activities by utilizing its natural lagoons and bay areas. Recreational diving facilities have

\footnotetext{
${ }^{2}$ The OBOR, which is known as 'the Belt and Road Initiative' is an economic and commercial development project that aimed at improving connectivity and cooperation among multiple states spread across the continents of Asia, Africa, and Europe.

${ }^{3}$ A carbon footprint is "the total set of GHG emissions caused directly and indirectly by an individual, organisation, event or product" (Ecometrica. 2008)
} 
a significant value in the tourism industry. Fortunately, Sri Lanka is also rich in maritime archaeology and anthropology and it is required to explore those areas for academic pursuits as well as one aspect of the tourism industry.

The developments of the tourism industry can generate thousands of new employment opportunities in Sri Lanka. Many local people can run even various domestic industries like making handcrafts which have involved with the tourism industry and generate extra income methods. This can alleviate the current crisis of poverty and unemployment up to some extent. It is important to mention the importance of paying full attention to coastal conservation and marine resource protection while promoting those tourism-related activities in those localities.

Sri Lanka is located in a strategically important place on the world geopolitical map. Hence, Sri Lanka has a great aptitude to become 'the guardian of the Indian Ocean.' In this way, Sri Lanka can open up many prospects in economic development by paying attention to the strategies related to oceanic protection. Those strategies include assuring the freedom of the sea routes by keeping the navigation channels free from pirates and military blockades. Sri Lanka has a great potential to involve in such kind of high-income generation methods by properly investing the resources of the Sri Lanka Navy.

Many areas of renewable energy which is a significant provision in both sustainable development and the Blue-Green economy could be developed by using the maritime resources of Sri Lanka. Renewable energy is known as 'clean energy.' There is abundant feasibility of generating electricity using sea waves and offshore wind power and OTEC (Oceanic Thermal Energy Conversion) technology. In this process, using the available resources and know-how, acquiring the support of the IGOs and INGOs like UNDP, JICA and GIZ and the ingenuity of human resources are essential.

The vast area of the coast of Sri Lanka is protected by mangroves which are highly useful coastal barriers and carbon absorbers. Those mangrove ecosystems act as huge storages of natural biodiversity. Many local people have their endemic livelihood activities linked with mangrove habitats. Those natural assets can make Sri Lanka the climate change a ready nation. The development of economic activities related to mangrove forests requires the intervention of the government with the proper mobilization of labor. Those activities act as defensive precautions which can assure that Sri Lanka is on track in combating climate change while boosting the economy in numerous ways.

Currently, the cover of the forests of Sri Lanka has decreased to 29.7 percent (Ministry of Mahaweli Development \& Environment, 2018). This amount is considered insufficient and this has drastically affected the changes in the prevailed climate patterns in Sri Lanka. Sri Lanka, as a small island nation is highly vulnerable to climate change and global warming. Therefore, immediate actions should be taken to regain the lost forest coverage. Consequently, the Ministry of Mahaweli Development and Environment has planned to distribute 200,000 plants per month under the campaign named 'Vana Ropa' (Daily Mirror, 2017).

Sri Lanka has outstanding potential in establishing Green Industrial Factories based on the principles of the Green Economy using its rich natural capital. One of the major concerns in Green Industrial Factories is employing necessary steps to maintain the low carbon emission in the entire production process. But in this case, there should be well established renewable energy sources as a prerequisite. Gradually, converting the factories into energy-efficient ones should be done systematically. In this post-civil war context of Sri Lanka, it can attract more foreign investments in the industrial and manufacturing sectors. Accordingly, many new factories can be established in economic zones. Sri Lanka can practice the concept of the Green Industry from the very beginning under these circumstances.

Green agricultural practice is another significant area of the Green Economy. In there, the inorganic and unhygienic agricultural sector in Sri Lanka should be replaced by organic agriculture practices with healthy methods. It can be identified that there is a very good demand for organic food crops including vegetables and fruits, in every nook and corner of the country due to health concerns of the public. This prevailing positive attitude of the people can be used towards the development of clean agricultural practices in Sri Lanka.

Sri Lanka has the opportunity to convert the prevailing ineffective fossil fuel-based energy sector into a Green one by using its rich natural resources. Sri Lanka can practice low loss transmission and efficient energy storage utilities by using its natural resources. The locally available raw materials like premium quality graphite deposits can be used in making power transmission lines with superconductors to create a low loss transmission network and to produce high capacity power storage battery devices. Currently, the Ceylon Electricity Board (CEB) is planning to redesign its master power supply strategy with the assistance of JICA. In this context, the above-mentioned sustainable energy-efficient strategies can be introduced to that new power plan from the very beginning (JICA, 2017).

Currently, Sri Lanka is undergoing a rapid development process with the intervention of the government and the private sectors. There is a great capability for adopting eco-friendly concepts like green cities and towns into urban development activities from

Page | 23 
the initial phase. Both the government and the private sector should be encouraged in the construction of green cities and villages by giving priority to sustainable development principles.

Sri Lanka has the most valuable opportunity in creating a Blue-Green economic workforce by mobilizing the unemployed youth in the country. Recently, the government of Sri Lanka has recruited a batch of fresh graduates into the public service. It can be used by these new recruiters to build a sustainable workforce in the country. In the end, those public officials can guide the entire nation towards achieving the SDGs by following the Blue-Green economic principles. Accordingly, there are many valuable opportunities within the country that Sri Lanka can shrewdly utilize by paying proper attention to achieving the SDGs by following the Blue-Green economic provisions.

6. The Challenges Encountered by Sri Lanka when Achieving the SDGs by Adopting the Blue-Green Economic Provisions The UNDP has recognized three major challenges which are common to any state in the implementation of the SDGs. The first one is the challenge in the governance mechanism of any country. This is about bringing together the right stakeholders as government, private sector and civil society at the right time in the right place for achieving a common objective. The second one is making difficult trade-offs. This is about balancing the competing interests of different parties which share a common objective. The third one is building accountability in action. This has been focused on methods of ensuring transparency, responsibility and responsiveness in this particular process (Bowen et al., 2017). These challenges are highly applicable to the Sri Lankan context also on different levels.

The problem in the governance mechanism is one of the severe issues which have adversely impacted achieving many development goals in Sri Lanka. In this case, each player in the process of governance as the government, the private sector and the civil society have not understood their role properly and as a result, they do not perform their part well (Ajward, Weerasinghe, 2012). Precisely, governance refers to how the actors of governance negotiate, make decisions and take actions. According to the perspective of most Sri Lankans, governance is all about power politics, but it is about the process, mechanism and strategies which are used to solve the problems in socio-economic and political sectors as well as to achieve development in those sectors.

There are myriads of failures in the current governance mechanism in Sri Lanka. One of the major issues is the decline of good governance practices. Consequently, the Sri Lankan governance mechanism has huge problems in the areas of participation of all stakeholders, consensus orientation, accountability, transparency, responsiveness, effectiveness and efficiency, equitability and inclusiveness and following the rule of law. It also needs to improve in the sectors like the legitimacy of actions, minimized corruptions, equal treatments for the minorities and that the voices of the most vulnerable in society are heard in decisionmaking, right to information, a long-term view of the public interest and the effectiveness in bureaucracy, etc. All the abovementioned requirements, which Sri Lanka is a lack of are highly essential to achieve the SDGs by following the Blue-Green economic approach.

The mechanism of the local-level governance in Sri Lanka has become ineffective and inefficient due to its inherited structural and functional weaknesses. This has highly affected the implementation of the agenda of the SDGs. There are many issues in the cooperate governance and E-governance practices also in Sri Lanka. All these prevailing weaknesses in the governance mechanism have impeded the programmes of both the SDGs and the Blue-Green economy in Sri Lanka.

There is a huge challenge in the achievement of SDGs, which is bringing together the right stakeholders at the right time in the right place. Both sustainable development and the Blue-Green economy by nature involve many different stakeholders operating at many different levels including national governments, Inter-Governmental Organizations (IGOs), Multi-National Corporations (MNCs) and Trans-National Corporations (TNCs), local and international NGOs, local governments, Civil Society Organizations (CSOs) and individuals. In Sri Lanka, it has been very difficult to establish a proper channel of coordination between those stakeholders and also bringing them together to solve the complexities in the agendas of the SDGs and the Blue-Green economy.

Making difficult trade-offs is also one of the major barriers that Sri Lanka is encountering in achieving the SDGs by following the Blue-Green economic provisions. Unlike previous development agendas that emphasize economic growth, the SDGs are a universal framework that contains many potentially diverging policy goals in the economic, social, and environmental sphere, while some goals are thought to be mutually supportive. The achievement of the agenda crucially depends on whether we will be able to maximize such synergies and resolve the existing trade-offs (Kroll et al., 2019). There may be trade-offs in the activities related to the SDGs also. A trade-off is "a situation in which you balance two opposing situations or qualities and, in some cases, it can be a situation in which you accept something bad to have something good" (Cambridge English Dictionary, 2021). In this

Page | 24 
situation, there will be both winners and losers, at least for the short term. Under this circumstance, the responsibility might be suppressed and the interests of different stakeholders might appear and clash with each other. Therefore, balancing the competing interests of the different stakeholder has become a real challenge in this process. Achieving the SDGs incorporating the Blue-Green economic principles requires a healthy dialogue between all stakeholders to make hard decisions based on a thoughtful and genuine commitment to the achievement of the SDGs.

The public administration and management system of Sri Lanka has many criticisms as highly bureaucratic and hierarchical oriented, outdated and corrupted (Ramasamy, 2020). The prevailing weaknesses in the public administration and management in Sri Lanka have impeded its performance. As a result of this, the government has become unable to properly implement public policies at the ground level. The procurement process of the government also has too many complex and time-wasting procedures. This situation has made private investors including foreign companies avoid investing in the development projects in Sri Lanka. The drawbacks in the New Public Management (NPM) practices and Public-Private Partnerships (PPPs) have also adversely affected the progress of achieving the SDGs in Sri Lanka.

Building public trust and awareness has also become a huge challenge in this process. The recent surveys reveal that Sri Lankan citizens have a low level of trust towards the policies and activities of the government. According to the Global Corruption Barometer for Sri Lanka survey only around 47 percent of the public trust the government. Approximately 80 percent consider corruption in the government to be a huge problem. The GCBSL survey indicates a rapid increase in corruption in areas related to climate change, natural resource utilization, and disaster management and 51 percent of the respondents believe that corruption is rampant in these sectors. This is a new development in Sri Lanka, and large-scale scandals were reported in the areas of environment and natural resource management involving political leaders and officials (Ramasamy, 2020). As a result of this prevailing corrupted political and administrative culture, Sri Lankan people have no longer faith in government programmes. This critical situation has adversely affected integrating and mobilizing the citizens into the journey of achieving SDGs by following the Blue-Green economic principles.

The high degree of politicization in the administrative sector and development programs has also affected negatively achieving both the SDGs and the deliberate outcomes of the Blue-Green economy in Sri Lanka. Thus, carrying out academic research and performance evaluations to assess the outcomes with genuine data is difficult in some of those programmes related to the SDGs and Blue-Green economy in Sri Lanka. Consequently, huge displacements of goals can be identified in this process. All those prevailing weaknesses have negatively impacted the overall implementation of these programmes.

As a result of the protracted civil war that dragged on for nearly three decades in Sri Lanka, there are many regional disparities in the development in the war-affected areas. Still, the war-affected areas are backward within the development process. As a result of the unequal distribution of resources, there are some underdeveloped areas in other regions of the country as well. The people in those underdeveloped areas do not have the potential to actively participate in development programmes due to the prevailing poverty and marginalization of them from the major stream of development. When attempting to launch any development activity in such an area, it should be provided with the basic needs of those localities first. In this manner, firstly, Sri Lanka has to fulfil some prerequisites including infrastructure development to facilitate both the programmes related to the SDGs and Blue-Green economic strategies.

Political instability has become a huge threat to the achievement of the SDGs by following the Blue-Green economic principles in Sri Lanka. The more frequent and sudden changes in the political sphere have made an inconsistency in public policies and development policies. For example, the legislative branch of the GoSL changed more than three times within two years from 2017 to 2019. Sri Lanka has the grave challenge of attracting foreign and local investors for development projects as a result of this unstable and chaotic political environment. The power struggle in the current political realm has become a catastrophe in achieving SDGs by following the Blue-Green economic approach.

The Covid-19 pandemic which emerged at the end of 2019 is significantly affecting the development of the entire human civilization. Due to this pandemic, the usual lifestyle of the people underwent enormous changes. No doubt, this adversely affected the entire development portfolios in the world. The measures which are taken to control this outbreak including the lockdown practices impede many economic activities in the world. This has also significantly affected ecosystems on the Earth. There are both positive and negative impacts of the Covid-19 pandemic on the environment. Some studies indicate that there are progressive improvements in the quality of air in different parts of the world (Rume \& Islam, 2020). At the same time, the emission of Green House Gases also has been reduced. Besides, there are some negative impacts of Covid-19 also. The unprecedented amount of increase of medical wastes like face masks has eventually polluted the environment. 
As viewed above, it can be concluded that various social, political, economic, and natural factors have imposed some barriers in the process of achieving the SDGs by adopting Blue-Green economic provisions in Sri Lanka.

\section{Recommendations to Overcome the Prevailing Challenges in Achieving the SDG by Adopting the Blue-Green Economic Provisions}

Sustainable development and the Blue-Green economy are two modern approaches to development which concerns balancing the different and competing needs that are against the awareness of the environmental, social and economic limitations in the world. Challenges and barriers are common in any social-transformative development agenda in any place in the world. As mentioned in the previous sections, there are both prospects as well as obstacles in achieving the SDGs by following the BlueGreen economy in Sri Lanka. However, there are many effective and efficient alternatives within the local environment that can be shrewdly applied to overcome those constraints. What should be done is to identify those alternative solutions properly and utilize them for making this process a success.

Both the SDGs and the Blue-Green economic concepts are known as people-driven transformative agendas built on the foundation of transparency, accountability, participation, and inclusion of the people. As a result, there are multiple actors in those processes. In this scenario, increasing the reciprocity, mutual trust, and recognition between each stakeholder should be done at every level to achieve the deliberate goals. There are multiple agencies responsible for implementing the distinct components of the SDGs and the Blue-Green economic provisions. There should be proper communication, coordination, and cooperation mechanism between them. Therefore, as an important initial recommendation, addressing the issues regarding raising the awareness and the education about these agendas among all stakeholders is a must.

During this study, it was identified that knowledge and proper understanding regarding both the SDGs and the Blue-Green economy rest among limited, particular strata in the society. In most cases, that strata comprised of (a) the top-level government officials, the IGO and the INGO members who are actively involved in this process, (b) academicians who are interested in these subject areas, and (c) a very few keen knowledge seekers who represent the ordinary society. The general public is not sufficiently aware or sometimes totally unaware of these agendas and as a result, their contribution is a missing link in this process. Therefore, nationwide awareness and education campaigns on the SDGs and the Blue-Green economic concepts are essential to address this situation. Through such campaigns, stakeholders should be able to gain knowledge, a sense of responsibility, and ownership towards achieving the SDGs and economic development based on the Blue-Green economic model. In these awareness-raising campaigns, both the mainstream mass media and social media should be used to reach diverse stakeholders on a tri-lingual (Sinhala, Tamil, and English Languages) basis in this process. Not only the central government and ministries but also the provincial and local government entities and private sector and civil society should actively participate in this mission. In there, all members of the society including women, senior citizens, school children, ethnic minorities, indigenous communities, differently-abled people, and other vulnerable communities also should take part in this agenda to make this a genuinely successful one.

Moreover, the school and university education system of Sri Lanka should be reformed by allocating some disciplines related to sustainable development and the Blue-Green economy in order to strengthen the students with the knowledge and skills related to these areas. This can prepare the younger generation for the new global trends, prospects, and demands in the contemporary professional sphere. This not only opens new career paths for them but also allows new inventions, ideas, and assets in these particular areas.

The public administration is the mechanism that transmits public policies which are taken in the upper level of the executive branch to the public and implements them at the grass-roots level in the society. It was described in a previous section about the prevailing weaknesses in the public administration and management sector in Sri Lanka. It is compulsory to take appropriate measures to eliminate those deficiencies in this sector to achieve the deliberate SDGs in Sri Lanka. The outdated public administrative system in Sri Lanka requires a sound reformation to increase administrative, management and technical capacities. Public officials should be fortified with tri-lingual proficiency, competency in Information and Communication Technology (ICT), and other relevant technical expertise. Minimizing the politicization and corruption in the public sector is also equally essential to achieve the SDGs by following the Blue-Green economic provisions.

The public policies and administrative regulations in Sri Lanka change according to the political changes, particularly due to the power shifts and this has become a negative trend in the public administrative culture in Sri Lanka. Consequently, the inconsistent nature of public policies and government programmes are some of the grave issues in meeting the development goals in Sri Lanka. As a result of this, policy and institutional coherence cannot be found in Sri Lankan administrative sector. It 
should be understood this harmful situation properly and introduced proper mechanism including constitutional provisions and other laws to establish stable and strong public policies and institutions in Sri Lanka.

The multi-stakeholder partnership is one of the significant elements of both the SDGs and the Blue-Green economy. In there, the government as the steering body has to balance the interests of each party in this process. In this case, the government must have good negotiation and problem-solving skills as it is working with multiple partners that have different affiliations and objectives. A people-centred governance mechanism can perform a huge role in this task. Here, it can be proposed to give priority to establishing a people-centred governance mechanism to achieve the SDGs and the objectives of the Blue-Green economy. This can promote the equal participation of every member of society in this process.

Enhancing accountability in the tasks of each organization working towards the achievement of the SDGs and Blue-Green economy is another significant recommendation we propose. In this regard, the government including respective ministries and other public institutions, IGOs, INGOs, private sector and civil society organizations should be accountable for their actions. Those institutions should be responsible for fulfilling their assigned duties within the appropriate framework which have been built upon the National Road Maps. Simultaneously, it is important to ensure that proper information on any procedure is available for any party at their request. The government must reveal accurate data about the progress of the programmes related to these areas without publishing fake statistics. Currently, the evaluation and monitoring mechanisms in these agendas have many shortcomings. Therefore, these procedures should be carried out by independent and impartial authorities.

The GoSL has an important task of attracting investments from the private sector and foreign institutions to fulfil the financial requirements including basic costs in the projects related to the SDGs and Blue-Green economic strategies. There must be strong democratic values in the country in the first place in order to attract investments from the private sector and foreign companies. This emphasized the importance of having a free and fair society based on the rule of law and other elements of good governance. Thus, creating a safe and healthy political environment that facilitate free businesses in the country is a timely requirement in fulfilling these goals. In the meantime, the government should be able to provide appropriate incentives to promote such investments in case of necessity.

It is essential to have a strong political will and commitment of the government in achieving the SDGs by following the BlueGreen economic strategies. The relevant agencies and authorities should be responsible for driving the public towards the achievement of these agendas. Meanwhile, it should be properly decentralized the activities and facilitated the proper flow of information in the society focusing on the process of implementing the SDGs and the Blue-Green economy in Sri Lanka.

It is the responsibility of the government to create an eco-friendly policy environment that reinforces the practices of the SDGs and the Blue-Green economy. Meanwhile, Sri Lanka should be able to get optimum benefits from its existing natural resources in achieving these targets rather than investing in new assets. It is essential to identify the aspects related to environmental sustainability, the possible use of existing resources, and other resource requirements in terms of financial, human capital, and technological know-how in the Sri Lankan context. If Sri Lanka is ready to recognize its prospects and challenges in the mission of achieving the SDGs by following the Blue-Green economic provisions and apply the appropriate recommendation to overcome those obstacles, then this task will no longer be a herculean mission.

\section{Conclusion}

Sustainable development and the Blue-Green economy have a close conceptual nexus and they mutually cooperate. In this case, Sri Lanka like many other states in the world, is also following the Blue-Green economic provisions to achieve the SDGs. The main objectives of this study were to identify the available opportunities and challenges for Sri Lanka in the process of achieving the SDGs by following the Blue-Green economic principles, and to present appropriate solutions to overcome those obstacles. Sri Lanka has taken noteworthy measures to achieve SDGs by adopting Blue-Green economic provisions, especially with the view of the fact that it is a developing island nation, which is highly vulnerable to natural disasters that affect all social, economic, and development activities. Sri Lanka is located in a strategically important place on the world geopolitical map with a lot of untouched marine resources and it is a remarkable prospect in achieving the SDGs by adopting the Blue Economy in Sri Lanka. It also has a great potential in stepping towards the Green economy, by incorporating environmentally friendly Green technologies into its ongoing massive development projects in this post-war context from the very beginning that contributes to the fulfilment of the agenda of SDGs. Meanwhile, Sri Lanka has some challenges and restraints also in the process of achieving the SDGs by following the Blue-Green economic principles. However, this study has found that those obstacles can be overcome by employing methods to address the issues in policy, governance, legal, economic areas. Develop the public sector with effectiveness and efficiency, proper technology transformation and information management, assist proper coordination between each stakeholder and also moving towards international cooperation and partnerships and expose to the global best practices in these relevant areas are also essential in this process. Mobilization of available resources including human resources, natural capital and other tangible assets, building the adaptive capacity of different communities, adopting climate-induced 
disaster risk management practices are some of the urgent requirements in the achievement of the SDGs through the BlueGreen economy. At the same time, it should be enhanced public accountability and transparency and promote awareness among citizens regarding these goals.

This study has mainly paid attention in examining opportunities and challenges for Sri Lanka in achieving the SDGs by adopting Blue-Green economic provisions, based on the initiatives taken by the Sri Lankan government authorities from 2016 to 2019 . The regime change in 2019 and the changing socio-economic and political conditions in Sri Lanka might have induced new opportunities and challenges in achieving SDGs in the post-2019 context. Additionally, the new global context of Covid-19 has also imposes a number of challenges for development initiatives. Therefore, possible studies focusing on the influence of the changing context of the socio-economic and political conditions in Sri Lanka in achieving SDGs will bring new findings in this research domain. Indeed, all governments in the world have to reorganize and reformulate their action plans for the SDGs by paying significant attention to the new normality caused by the Covid-19 epidemic situation. If Sri Lanka is ready to identify the above-mentioned priority areas and address them accurately, it can implement Blue-Green economic provisions successfully and ultimately accomplish the SDGs by the year 2030 .

Funding: This research is self-funded by the authors.

Acknowledgments: The authors would like to express their gratitude to those who helped in many ways for this study.

Conflicts of Interest: The authors declare no conflict of interest about any aspect of this study.

\section{References}

[1] Ben-Eli, M. (2015). Sustainability: Definition and Five Core Principles - A New Framework. The Sustainability Laboratory Retrieved 20 December, 2021 from: http://www.sustainabilitylabs.org/assets/img/SL5CorePrinciples.pdf

[2] Bio Energy Association of Sri Lanka. (2016). Sri Lanka NEXT: A Blue-Green Era. Retrieved 16 October, 2020 from: https://www.bioenergysrilanka.lk/sri-lanka-next-a-blue-green-era/

[3] Borel-Saladin, J.M., \& Turok, I.N. (2013). The Green Economy: Incremental Change or Transformation? Environmental Policy and Governance, 23(4), 209-220.

[4] Bowen, K. J., Henry, N. C., Koch, F., Patterson, J., Häyhä, T., Vogt, J., \& Babri, F. (2017). Implementing the "Sustainable Development Goals": Towards Addressing Three Key Governance Challenges-Collective Action, Trade-offs, and Accountability. Current Opinion in Environmental Sustainability. 26-27, 90-96.

[5] Cambridge Dictionary. (2021). Trade-off meaning. Cambridge University Press. Retrieved 07 April from: https://dictionary.cambridge.org/dictionary/english/trade-off.

[6] Carbon Trust, (2008). What is a Carbon Footprint?. Retrieved 28 February 2021 from: https://ecometrica.com/what-is-a-carbon-footprint/

[7] Comporek, M., Kowalska, M., \& Misztal, A. (2021). The Sustainable Development of Transport Enterprises in the Context of Microeconomic Conditions: The Cash of Central and Eastern European Countries. Entrepreneurship and Sustainability Issues, 8(3), 226-247.

[8] Fedrigo-Fazio, D., \& Brink, P.T. (2012). Briefing Green Economy: What do We Mean by Green Economy?. Nairobi: United Nations Environment Program.

[9] Fernandopulle, S. (2017). A Blue-Green Era in Sri Lanka. Daily Mirror. (24 October).

[10] Georgeson, L., Maslin, M., \& Poessinouw, M. (2017). The Global Green Economy: A Review of Concepts, Definitions, Measurement Methodologies and Their Interactions. Geo: Geography and Environment, 4 (1), e00036.

[11] Global Environment Facility. (2018). Blue Economy. [Online] Retrieved 16 October, 2020 from: https://www.thegef.org/sites/default/files/publications/GEF\%20Assembly_BlueEconomy\%20Factsheet_6.19.18.pdf

[12] Guo, M., Nowakoska-Grunt, J., Gorbanyov, J., \& Egorova, M. (2020). Green Technology and Sustainable Development: Assessment and Green Growth Frameworks. Sustainability, 12, 6571.

[13] JICA. (2016). JICA's Support for the Project on Electricity Sector Master Plan Study. Retrieved 05 November, 2020 from: https://www.jica.go.jp/srilanka/english/office/topics/press160401.html

[14] Klarin, T. (2018). The Concept of Sustainable Development: From its Beginning to the Contemporary Issues. Zagreb International Review of Economics \& Business, 21(1), 67-94.

[15] Kroll, C., Warchold, A., \& Pradhan, P. (2019). Sustainable Development Goals (SDGs): Are We Successful in Turning Trade-offs into Synergies?. Palgrave Communications, 5, 140.

[16] Kuo, C. S. (2015). 2012 Minerals Yearbook Sri Lanka. Retrieved 20 October, 2020 from: https://s3-us-west-2.amazonaws.com/prdwret/assets/palladium/production/mineralpubs/country/2012/myb3-2012-ce.pdf

[17] Mensah, J. (2019). Sustainable Development: Meaning, History, Principles, Pillars, and Implications for Human Action: Literature Review, Cogent Social Sciences, 5(1), 1653531.

[18] Ministry of Mahaweli Development \& Environment. (2018). Forest Department - Performance Report. Retrieved 17 October, 2020 from: https://www.parliament.lk/uploads/documents/paperspresented/performance-report-forest-department-2018.pdf

[19] Okafor-Yarwood, I., Kadagi, N.I., Miranda, N.A.F., Uku, J., Elegbede, I.O \& Adewumi, I.J. (2020). The Blue Economy-Cultural LivelihoodEcosystem Conservation Triangle: The African Experience. Frontier in Maritime Science, 7, 586.

[20] Ramasamy, R. (2020). Governance and Administration in Sri Lanka: Trends, Tensions, and Prospects. Public Administration and Policy, 23(2), 187-198. 
[21] United Nations. (2013). Global Sustainable Development Report - Executive Summary: Building the Common Future We Want. New York: United Nations Department of Economic and Social Affairs, Division for Sustainable Development. 2013, Retrieved 18 October, 2020 from: http://sustainabledevelopment.un.org/globalsdreport/

[22] Reyes, G. E. (2001). Four Main Theories of Development: Modernization, Dependency, Word-system, and Globalization. Nómadas. Revista Crítica de Ciencias Sociales y Jurídicas, 4(2), 109-124.

[23] Rume, T., Islam, S. M. D. U. (2020). Environmental Effects of COVID-19 Pandemic and Potential Strategies of Sustainability. Heliyon, 6(9), e04965.

[24] Schaefer, F., Luksch, U., Steinbach, N., Cabeça, J., Hanauer, J. (2006). Ecological Footprint and Biocapacity: The World's Ability to Regenerate Resources and Absorb Waste in a Limited Time Period. Luxembourg: Office for Official Publications of the European Communities.

[25] Schrijver, N. (2010). Development Without Destruction: The UN and Global Resource Management. Indiana: Indiana University Press.

[26] Stoddart, H., Schneeberger, K., Dodds, F., Shaw, A., Bottero, M., Cornforth, J., \& White, R. (2011). A Pocket Guide to Sustainable Development Governance. (n.a): Stakeholder Forum.

[27] Straaten, J. V. D., \& Tylecote, A. (1997). Environment, Technology and Economic Growth: The Challenge to Sustainable Development. Glos: Edward Elgar Publishing Limited.

[28] The World Bank. (2017). The Potential of the Blue Economy: Increasing Long-term Benefits of the Sustainable Use of Marine Resources for Small Island Developing States and Coastal Least Developed Countries. Washington DC: The World Bank.

[29] Thomas, C. F. (2015). Naturalizing Sustainability Discourse: Paradigm, Practices and Pedagogy of Thoreau, Leopold, Carson and Wilson: Ph.D Thesis: Arizona State University.

[30] Todaro, M. P., \& Smith, S. C. (2006). Economic Development (8th ed.). Reading: Addison-Wesley.

[31] UNCTAD. (2014). The Oceans Economy: Opportunities and Challenges for Small Island Developing States. New York: United Nations Conference on Trade and Development.

[32] UNEP. (2011). Towards a Green Economy: Pathways to Sustainable Development and Poverty Eradication - A Synthesis for Policy Makers Retrieved 16 October, 2021 from: www.unep.org/greeneconomyhttps://sustainabledevelopment.un.org/content/documents/126GER_synthesis_en.pdf

[33] UNEP, FAO, IMO, UNDP, IUCN, World Fish Center, GRID Arendal, (2012), Green Economy in a Blue World. Retrieved 18 October, 2020 from: https://unctad.org/system/files/non-official-document/ted-ditc-05122016-cancun-GreenEconomy-Blue-unep.pdf

[34] United Nations Development Programme. (2012). Green Economy in Action: Articles and Experts that Illustrate Green Economy and Sustainable Development Efforts. Retrieved 15 October, 2020 from: https://www.un.org/waterforlifedecade/pdf/green_economy_in_action_eng.pdf

[35] United Nations Environmental Program. (2012). Green Economy in a Blue World. Nairobi: United Nations Environmental Program. Retrieved 18 October, 2020 from: https://unctad.org/system/files/non-official-document/ted-ditc-05122016-cancun-GreenEconomy-Blueunep.pdf

[36] United Nations. (2012). Blue Economy Concept Paper. Retrieved 17 October, 2020 from: https://sustainabledevelopment.un.org/content/documents/2978BEconcept.pdf

[37] United Nations, World Bank Group. (2017). The Potential of the Blue Economy: Increasing Long-term Benefits of the Sustainable Use of Marine Resources for Small Island Developing States and Coastal Least Developed Countries. Retrieved 16 October, 2020 from https://sustainabledevelopment.un.org/content/documents/2446blueeconomy.pdf

[38] United Nations. (2015). General Assembly: Resolution Adopted by the General Assembly on 25 September 2015 . Retrieved 01 October, 2020 from: https://www.un.org/ga/search/view_doc.asp?symbol=A/RES/70/1\&Lang=E

[39] Weerasinghe, W., Ajward, R. (2019). Issues of Corporate Governance Practices in Sri Lanka: Perceptions of Professionals. CA Journal of Applied Research, 1(1), 1-19.

[40] Wenhai L., Cusack C., Baker M., Tao W., Mingbao C., Paige K., Xiaofan Z., Levin L., Escobar E., Amon D., Yue Y., Reitz A., Neves AAS., O'Rourke E., Mannarini G., Pearlman J., Tinker J.., Horsburgh KJ, Lehodey P., Pouliquen S., Dale T., Peng, Z \& Yufeng, Y. (2019). Successful Blue Economy Examples with an Emphasis on International Perspectives. Frontier in Maritime Science, 6, 261. 